\title{
PENERAPAN MODEL INDUKTIF DENGAN MEDIA GAMBAR SILLUET DALAM PEMBELAJARAN MENULIS TEKS CERITA PENDEK
}

(Penelitian Eksperimen Kuasi pada Siswa Kelas XI SMK Negeri 1 Cimahi Tahun

Ajaran 2014/2015)

Nikke Permata Indah

Pendidikan Bahasa Indonesia

Sekolah Pascasarjana

Universitas Pendidikan Indonesia

nikkepermata@student.upi.edu

\begin{abstract}
Abstrak
Tujuan dalam penelitian ini salah satunya adalah untuk mengetahui apakah terdapat perbedaan yang signifikan antara kemampuan menulis cerpen siswa pada kelas eksperimen dan kelas kontrol. Pembelajaran sastra selalu dianggap membosankan karena cara pengajarannya yang monoton sehingga siswa merasa bosan. Menulis Cerpen merupakan salah satu pembelajaran sastra yang harus dikuasai oleh siswa. Namun, seringkali siswa mengalami kesulitan dalam pembelajaran menulis cerpen karena berbagai faktor. Berdasarkan hal tersebut dilakukan penilitian dengan menggunakan metode eksperimen kuasi yang menggunakan pendekatan kuantitatif. Populasi pada penelitian ini adalah kelas XI SMKN 1 Cimahi tahun ajaran 2014/2015, sedangkan sampel pada penelitian ini adalah kelas KP B sebagai kelas eksperimen dan kelas Eind B sebagai kelas kontrol. Adapun teknik pengumpulan data yang digunakan dalam penelitian ini adalah teknik tes yaitu berupa tes awal dan tes akhir.Berdasarkan perhitungan uji t hipotesis, diperoleh hasil $\mathrm{t}_{\text {tabel }} \leq \mathrm{t}_{\text {hitung }} \geq \mathrm{t}_{\text {tabel }}$, yaitu $1,939 \leq 9,01 \geq 1,939$. Hal ini menunjukkan bahwa $\mathrm{H}_{\mathrm{a}}$ diterima dan $\mathrm{H}_{0}$ ditolak. Dengan demikian, dapat disimpulkan bahwa terdapat perbedaan yang signifikan antara kemampuan menulis teks cerita pendek siswa di kelas eksperimen sebelum dan sesudah menggunakan model induktif dengan menggunakan media gambar siluet terbukti efektif.
\end{abstract}

Kata kunci: Model induktif, Teks Cerpen, Media dan Gambar Siluet 


\section{PENDAHULUAN}

Pengajaran sastra di SMA, SMK dan sederajat selalu mendapatkan banyak perhatian. Pembicaraan masalah pengajaran sastra sudah sering dimuat di berbagai media, baik yang bersifat kritik, saran, maupun penjabarannya, bahkan tidak jarang pembicaraan itu memuncak jadi perdebatan (Danardana, 2013, hlm. 17). Pembelajaran sastra selalu terdapat keluhan, terutama dari cara pengajarannya yang monoton dan membuat siswa merasa bosan sehingga mereka kurang menyukai pembelajaran sastra.

Ahmad Badrun dalam Danardana (2013, hlm.17) membahas topik yang sama yaitu bagaimana agar proses belajar mengajar sastra dapat berjalan dengan baik. Tulisan Ahmad Badrun pada intinya meninjau kembali pengajaran sastra di SMA, bukan hanya di SMA, namun juga di SMK dan sederajat yang akhir-akhir ini sering dijadikan topik utama, antara lain bahwa pengajarannya masih bersifat teoretis, tidak berorientasi pada karya sastra dan tidak dilaksanakan dengan baik akibat kurangnya fasilitas. Pembahasan Ahmad Badrun tentang pembelajaran sastra masih sama pada tahun 2015. Sastra masih kurang diminati bahkan sering kali dikesampingkan karena pengajaran yang masih bersifat teoretis dan konvensional.

Ahmad Badrun dalam Danardana (2013, hlm. 17) menyarankan agar pengajaran sastra dapat diatasi yaitu sebagai berikut.

1) guru yang berkualitas;

2) pengadaan fasilitas; dan

3) penggunaan metode yang tepat.

Saran dari Ahmad Badrun sangat sulit untuk dibantah seperti masalah guru, fasilitas dan metode yang tepat. Ketiganya merupakan modal dasar tercapainya tujuan pengajaran sastra. Namun, bukan hanya dari metode yang tepat, model dan pendekatan pembelajaran juga harus diperhatikan.

Pengajaran sastra dianggap kurang berhasil dari diskusi sastra antarsiswa SMA yang diselenggarakan oleh pengembangan bahasa. Siswa SMA berpendapat bahwa sastra dapat memberi manfaat namun tidak semua menyukai sastra karena 
cara mengajar guru yang dianggap monoton dan kurang menarik, akibatnya siswa semata-mata belajar sastra hanya bagian dari mata pelajaran Bahasa Indonesia (Danardana, 2013, hlm. 22). Siswa SMA saja kurang menyukai pembelajaran sastra karena cara mengajar guru yang monoton, apalagi siswa SMK dan sederajat yang merasa bosan dan menganggap kurang pentingnya pembelajaran sastra.

Hal yang harus diperhatikan dari diskusi antarsiswa SMA tersebut adalah pertama, siswa hanya menyukai sastra sebagai hiburan. Kedua, siswa belajar sastra hanya karena bagian dari mata pelajaran Bahasa Indonesia. ketiga, siswa merasa bosan pada pembelajaran sastra karena cara mengajar guru dianggap kurang menarik dan pengajaran sastra bersifat teoretis, sedangkan jika dilihat dari tujuan umum pengajaran sastra menurut Depdiknas (2003, hlm. 2):

Pengajaran sastra adalah agar siswa mampu menikmati, menghayati, memahami, dan memanfaatkan karya sastra untuk mengembangkan kepribadian, memperluas wawasan kehidupan serta meningkatkan pengetahuan dan kemampuan berbahasa.

Tujuan pengajaran sastra secara khusus adalah sebagai berikut.

1) Agar siswa menguasai ciri-ciri pembentuk puisi, prosa, drama, kritik, dan esai,

2) Agar siswa mampu menikmati, menghayati, memahami, dan menarik manfaat karya-karya sastra, dan

3) Agar siswa peka terhadap lingkungan dan mampu mengungkapkan secara kreatif sesuai dengan konteks dan situasi.

Bertolak dari tujuan tersebut, maka pembelajaran Bahasa dan Sastra Indonesia harus diarahkan kepada pencapaian sasaran tersebut. Pertanyaan yang muncul kemudian adalah tindakan seperti apa dan bagaimana itu? Oleh karena itu, seorang guru sastra harus mampu memilih model pembelajaran dan media yang variatif, tidak menggunakan pengajaran yang monoton sehingga membuat siswa merasa bosan. Menulis cerpen merupakan salah satu pembelajaran sastra yang diterapkan di Sekolah Menengah Atas. Pembelajaran menulis kerpen sebagian besar bersifat teoretis, dan kurangnya buku penunjang. Karena permasalahan itu, menulis cerpen kurang diminati, pengajar harus menggunakan model yang tepat dalam pembelajaran menulis cerpen, 
Dari latar belakang tersebut dilakukan penelitian dengan judul "Penerapan Model Induktif dengan Media Gambar Siluet dalam Pembelajaran Menulis Cerpen di SMKN 1 Cimahi Tahun Ajaran 2014-2015”. Penelitian ini diharapkan dapat menemukan model pengajaran yang efektif dengan media yang tepat dalam pembelajaran sastra terutama menulis cerpen.

Model pembelajaran dan pengajaran induktif dirancang untuk melatih siswa membuat konsep dan sekaligus untuk mengajarkan konsep-konsep dengan cara penerapannya pada mereka. Tahap-tahap model induktif adalah mengumpulkan informasi, membuat konsep kemudian mengubah konsep menjadi hipotesis.

Hilda Taba dalam Joyce (2009, hlm. 107) mengatakan bahwa model induktif sangat penting diterapkan di dalam kelas. Taba dapat disebut sebagai orang pertama yang mempopulerkan istilah strategi pengajaran dan model induktif sehingga strategi dan model tersebut bisa digunakan dengan mudah untuk merancang kurikulum dan pembelajaran.

Model induktif dapat membantu siswa mengumpulkan informasi dan mengujinya dengan teliti, kemudian mengolah informasi ke dalam bentuk konsep dan belajar memanipulasi konsep-konsep tersebut. Strategi ini juga dapat meningkatkan kemampuan siswa untuk membentuk konsep-konsep secara efisien dan meningkatkan ketajaman siswa dalam memandang suatu informasi.

Konsep yang disebut Joyce sebagai syntax yaitu struktur pengajaran yang merupakan elemen-elemen atau tahap-tahap yang paling penting untuk memberikan pedoman bagaimana pembelajaran model induktif diterapkan. Model induktif memiliki struktur pemutaran yang berkembang setiap waktu, penelitian induktif hampir tidak pernah singkat. Esensi proses induktif adalah pengumpulan dan penyaringan informasi tanpa henti, pembangunan gagasan, khususnya kategorikategori yang menyediakan kontrol konseptual atas daerah-daerah informasi, penciptaan hipotesis untuk dieksplorasi dalam upaya memahami hubunganhubungan yang lebih baik atau menyediakan solusi untuk berbagai masalah dan perubahan menjadi keterampilan yang memiliki aplikasi praktis. 
Peneliti menggunakan model berpikir induktif dengan media gambar siluet dalam pembelajaran menulis cerpen yaitu karena gambar siluet berfungsi untuk membantu penyampaian dan pengumpulan informasi kepada siswa. Siluet memiliki keunikan tersendiri, terdapat misteri-misteri di dalam gambarnya, sehingga siswa dapat menginterpretasi gambar tersebut dengan imajinasi yang kreatif.

Media gambar siluet mempermudah proses kegiatan belajar mengajar, menambah kreativitas siswa serta menambah pengetahuan tentang gambar siluet yang akan digunakan. Siswa dapat menulis cerpen lebih baik dengan interpretasi dari gambar siluet. Siluet dapat membantu menghasilkan ide, jalan cerita dan konflik karena warna hitam-putih dalam siluet mengandung misteri sehingga menimbulkan penafsiran yang berbeda-beda.

Sumardjo (2004, hlm. 97) berpendapat bahwa menulis diperlukan adanya latihan. Latihan menulis perlu terus - menerus dilakukan seperti halnya seorang pelukis melatih dirinya membuat sketsa - sketsa. Keterampilan menulis adalah keterampilan mengatakan sesuatu hingga menjadi jelas bagi orang lain, memang perlu latihan dan belajar. Keahlian untuk bisa memberikan gambaran sesuatu tak mungkin diperoleh hanya dengan bakat alam, dengan latihan - latihan akhirnya akan ditemukan gaya menulis. Cara seorang pengarang menggambarkan suatu kenyataan mencerminkan pribadi gaya hidupnya sendiri.

Pembelajaran menulis cerpen adalah salah satu pembelajaran Bahasa Indonesia di sekolah menengah atas. Menulis cerpen dapat dikatakan menuliskan cerita pendek yang fiktif. Cerita yang dekat dengan kehidupan nyata dan fantasi pembaca atau angan-angan. Pembelajaran menulis sastra dapat mengembangkan kreatifitas siswa, mengembangkan daya imajinasi dan siswa dapat bebas berkarya menuangkan ide-idenya ke dalam tulisan. Siswa akan terlatih menulis dengan adanya kompetensi dasar menulis dan siswa tidak canggung lagi menuangkan ideide kreatifnya dalam tulisan terutama cerpen.

Penelitian serupa dengan penelitian ini yang berkaitan dengan model induktif dalam pembelajaran sastra yaitu

(1) Peningkatan Kemampuan 
Mengapresiasi Cerpen Dengan Menggunakan Model Pembelajaran Induktif Pada Siswa Kelas VIIB SMP Islam Unggaran, (Agus Riyanto, 2009). (2) Peningkatan Kemampuan Apresiasi Cerpen Dengan Menggunakan Model Taba Pada Mata Pelajaran Bahasa Indonesia Siswa Kelas V SDN 01 Tegalrejo Musi Rawas, (Lilismawati, 2009).

Kedua penelitian di atas berupa peningkatan kemampuan apresiasi cerpen tanpa menggunakan media, dan jenis penelitian keduanya adalah PTK. Hasil dari kedua penelitian tersebut menunjukkan bahwa model pembelajaran induktif dapat meningkatkan kemampuan mengapresiasi cerpen pada siswa. Kedua penelitian di atas tidak menggunakan media maka dari itu dilakukan penelitian dengan media gambar siluet dalam pembelajaran menulis cerpen dengan jenis penelitian eksperimen.

\section{METODE PENELITIAN}

Berdasarkan jenis data yang digunakan penelitian ini dikategorikan sebagai penelitian kuntitatif. Penelitian yang penulis lakukan menggunakan penelitian eksperimen melalui penerapan kelas kontrol dan kelas eksperimen yang akan diuji dengan pengujian statistik berupa uji t. Penelitian eksperimen adalah penelitian untuk menyelidiki kemungkinan hubungan sebab-akibat dengan cara mengekspos satu atau lebih kelompok eksperimental dan satu atau lebih kondisi eksperimen. Hasilnya dibandingkan dengan satu kelompok atau lebih dengan kelompok kontrol yang tidak diberi perlakuan (Syamsudin A.R \& Vismaia, 2011, hlm.151)

Populasi dalam penelitian ini adalah seluruh siswa kelas XI SMKN 1 Cimahi tahun ajaran 2014-2015. Jumlah seluruh siswa kelas XI SMKN Negeri 1 Cimahi adalah 1850 siswa, yang terdiri dari 1291 siswa laki-laki dan 559 siswa perempuan.

Populasi dalam penelitian ini adalah seluruh siswa kelas XI SMKN 1 Cimahi tahun ajaran 2014-2015. Jumlah seluruh siswa kelas XI SMKN Negeri 1 Cimahi adalah 1850 siswa, yang terdiri dari 1291 siswa laki-laki dan 559 siswa perempuan. Pemilihan populasi penelitian di SMKN 1 Cimahi adalah karena 
sekolah kejuruan teknik nomor 1 di Cimahi yang berada di tengah perkotaan yang biasanya terdiri dari beragam kalangan siswa. Kenapa mengambil sekolah kejuruan? Karena siswa kejuruan terutama teknik biasanya merasa kesulitan dalam pembelajaran sastra khusunya cerpen. Mereka juga merasa bosan dengan pembelajaran sastra yang dirasa monoton, sehingga tepat dipilih sebagai populasi untuk menerapkan model berpikir induktif dengan media gambar siluet, agar pengetahuan sastra mereka dapat bertambah terutama dengan gambar siluet.

Penentuan sampel dalam penelitian ini menggunakan teknik sampel insidental karena pemilihan sampel dilakukan secara kebetulan yaitu siapa saja yang kebetulan bertemu dapat digunakan sebagai sampel, bila orang yang kebetulan ditemui itu cocok sebagai sumber data (Sugiyono, 2013, hlm.85). Yakni kelas XI KP B sebagai kelas eksperimen dan kelas kontrol yakni kelas XI EIND B.

Teknik pengumpulan data yang dilakukan dalam penelitian ini meliputi instrumen penelitian, instrumen perlakuan, instrumen tes dan instrumen observasi.

\section{HASIL DAN PEMBAHASAN}

\section{HASIL}

Dari hasil uji hipotesis yang telah dilakukan, kemampuan menulis cerita pendek kelas eksperimen sebelum dan sesudah mengikuti pembelajaran menggunakan model induktif dengan media gambar siluet terbukti efektif. Setelah melakukan perhitungan prasyarat analisis data, diketahui bahwa data sampel penelitian terbukti memiliki taraf reliabilitas tinggi, berdistribusi normal, dan homogen dengan taraf kepercayaan $95 \%$.

\section{PEMBAHASAN}

Setelah data terbukti normal dan homogen berdasarkan hasil pengujian normalitas dan homogenitas sebagai tahap pengujian persyaratan analisis data, maka langkah selanjutnya adalah menguji hipotesis dengan rumus uji-t ( $t$-test). Peneliti menggunakan uji-t karena penelitian ini merupakan penelitian yang menggunakan 
kelompok eksperimen dan kelompok kontrol. Uji hipotesis dilakukan untuk menguji signifikansi perbedaan mean. Hipotesisnya adalah sebagai berikut.

Hipotesis alternatif $(\mathrm{Ha}) \quad$ : Terdapat perbedaan yang signifikan antara kemampuan menulis teks cerita pendek siswa di kelas eksperimen dan kelas kontrol setelah menggunakan model berpikir induktif dengan media gambar siluet .

Hipotesis nol (Ho) : Tidak terdapat perbedaan yang signifikan antara kemampuan menulis teks cerita pendek siswa di kelas eksperimen dan kelas kontrol setelah menggunakan model pembelajaran induktif dengan media gambar siluet.

Hipotesis yang digunakan dalam penelitian ini adalah hipotesis alternatif.

Berdasarkan perhitungan uji hipotesis maka diperoleh $\mathrm{t}_{\text {tabel }} \leq \mathrm{t}_{\text {hitung }} \geq \mathrm{t}_{\text {tabel }}$, yaitu $1,939 \leq 9,01 \geq 1,939$. Hal ini menunjukkan bahwa $\mathrm{H}_{\mathrm{a}}$ diterima dan $\mathrm{H}_{0}$ ditolak. Berdasarkan hasil pengujian hipotesis ini dapat disimpulkan bahwa model induktif dalam pembelajaran menulis teks cerita pendek terbukti efektif.

Dari kelas eksperimen dan kelas kontrol terlihat ada perbedaan yang signifikan. Di kelas eksperimen dan kontrol nilai rata-rata tes awal siswa berada dalam kategori yang sama yaitu cukup (72) dan (71). Nilai rata-rata siswa di kelas eksperimen berada dalam kategori baik (84) dan nilai rata - rata siswa kelas kontrol berada dalam kategori cukup (74).

Secara garis besar, kemampuan siswa dalam menulis cerpen di kelas eksperimen mengalami perbedaan yang signifikan setelah diterapkannya model pembelajaran induktif dengan media gambar siluet. Masalah-masalah yang dialami siswa ketika menulis cerpen, seperti kesulitan dalam mencari ide, merangkai kata dan menuangkan gagasan tidak lagi dialami siswa. Siluet sebagai media membantu siswa belajar mencari ide dengan apa yang dilihat dan mengembangkan menjadi sebuah cerita. Misteri siluet yang dihadirkan mampu memberikan ide dengan rangkaian kata yang indah dan model induktif mengarahkan siswa menemukan konsep sesuai pemahamannya dengan pengalamannya. Pengalaman disini bukan 
berarti pengalaman kehidupan siswa sendiri, tapi bisa jadi pengalaman orang lain yang siswa lihat. Pengalaman siswa yang didapat adalah dengan melihat gambar siluet dengan segala misteri dan masalah yang terdapat di dalam gambar tersebut dapat menghadirkan ide dalam benak siswa sesuai imajinasinya.

Setelah diterapkannya model pembelajaran induktif dengan media gambar siluet, kemampuan siswa dalam menyusun dan mengembangkan aspek kepaduan unsur atau struktur cerpen mengalami peningkatan. Siswa yang pada awalnya belum dapat membangun alur yang sesuai dengan kaidah dan penahapan alur, mengalami peningkatan sehingga cerpen yang dihasilkannya dibangun oleh alur yang dapat menimbulkan rasa ingin tahu dan kejutan, serta menghadirkan tahapan alur yang saling berhubungan satu sama lain.

Dimensi tokoh dan dimensi latar yang tadinya masih belum terlihat, mulai tampak, siswa berhasil memberikan penggambaran latar dengan menggunakan pilihan kata yang tepat sehingga pembaca dapat dengan mudah mengikuti alur cerita.

Kesalahan dalam penggunaan EYD dari tes awal tidak terlalu banyak kesalahan hanya kesalahan penulisan kata akibat terburu-buru dan tes akhir juga semakin baik hanya masih ada kesalahan tanda baca seperti titik (.) dan koma (,).

Berdasarkan hasil data tersebut, maka dapat disimpulkan bahwa model induktif dengan mengunakan media gambar siluet terbukti efektif dalam pembelajaran menulis teks cerita pendek siswa. Hasil penelitian ini menjawab dan membuktikan hipotesis bahwa terdapat perbedaan yang signifikan antara kemampuan siswa dalam menulis cerpen di kelas eksperimen dengan kelas kontrol.

\section{SIMPULAN}

1) Kemampuan siswa dalam menulis teks cerita pendek pada tes awal di kelas eksperimen sebelum diberi perlakuan berupa penerapan Model Induktif dengan menggunakan gambar siluet memperoleh nilai rata-rata 72 termasuk ke dalam 
kategori cukup. Nilai tertinggi 79 dan nilai terendah 62 yang keduanya termasuk dalam kategori cukup. Sementara itu, kemampuan siswa dalam menulis teks cerita pendek pada tes akhir di kelas eksperimen setelah diberikan perlakuan berupa penerapan Model Induktif dengan menggunakan gambar siluet memperoleh nilai rata-rata 84 termasuk dalam kategori baik, nilai tertinggi 90 termasuk dalam kategori sangat baik dan nilai terendah 75 termasuk ke dalam kategori cukup. Nilai tersebut menunjukkan terdapatnya perbedaan yang signifikan pada kemampuan menulis teks cerita pendek sebelum dan sesudah diberi perlakuan Model Induktif dengan menggunakan gambar siluet berupa penerapan pada siswa kelas eksperimen.

2) Kemampuan siswa dalam menulis teks cerita pendek pada tes awal di kelas kontrol sebelum diberi perlakuan berupa penerapan model terlangsung memperoleh nilai rata-rata 71 termasuk ke dalam kategori cukup. Nilai tertinggi 74 dan nilai terendah 63 yang keduanya termasuk ke dalam kategori cukup. Sementara itu, kemampuan siswa dalam menulis teks cerita pendek pada tes akhir di kelas kontrol setelah diberikan perlakuan berupa penerapan model terlangsung memperoleh nilai rata-rata 74 termasuk ke dalam kategori cukup. Nilai tertinggi 77 dan nilai terendah 69 yang keduanya termasuk ke dalam kategori cukup. Namun, peningkatan tersebut tidak signifikan seperti pada kelas eksperimen.

3) Berdasarkan perhitungan uji t hipotesis, diperoleh hasil $t_{\text {tabel }} \leq t_{\text {hitung }} \geq t_{\text {tabel }}$, yaitu $1,939 \leq 9,01 \geq 1,939$. Hal ini menunjukkan bahwa $\mathrm{H}_{\mathrm{a}}$ diterima dan $\mathrm{H}_{0}$ ditolak. Dengan demikian, dapat disimpulkan bahwa terdapat perbedaan yang signifikan antara kemampuan menulis teks cerita pendek siswa di kelas eksperimen sebelum dan sesudah menggunakan model induktif dengan menggunakan media gambar siluet dengan kemampuan menulis teks cerita pendek siswa di kelas kontrol sebelum dan sesudah menggunakan model terlangsung. Hal ini dapat dilihat dari peningkatan nilai rata-rata kemampuan menulis teks cerita pendek siswa pada kedua kelas sebelum dan setelah diberi perlakuan. Dapat diketahui bahwa kelas eksperimen memiliki peningkatan nilai yang lebih tinggi, yakni dari 
65 menjadi 87 dengan peningkatan sebesar 22, sedangkan kelas kontrol hanya meningkat dari 63 menjadi 74 dengan peningkatan sebesar 11. Dapat terlihat juga dari nilai rata-rata kelas eksperimen ketika tes awal mendapat nilai 72 kemudian setelah perlakuan mendapat nilai 84 dengan peningkatan 12 sedangkan di kelas kontrol hanya meningkat dari 71 menjadi 74 dengan peningkatan sebesar 3. Hal ini menunjukkan Perlakuan yang diberikan di kelas eksperimen menggunakan model induktif dengan media gambar siluet terbukti lebih efektif dibandingkan dengan perlakuan yang diberikan di kelas kontrol dengan menggunakan model terlangsung.

\section{Daftar Pustaka}

Syamsudin A.R \& Vismaia. (2011). Metode penelitian pendidikan bahasa. Bandung: Rosdakarya.

Arikunto, S. (2002). Prosedur penelitian. Jakarta: Rineka Cipta.

Danardana, A. (2013). Pelangi sastra . Pekanbaru: Palagan Press

Departemen Pendidikan Nasional. 2003. Pengembangan kurikulum dan sistem penilaian berbasisi kompetensi. Jakarta: Depdiknas. 
Joyce, B, dkk. (2009). Models of teaching model-model pengajaran edisi kedelapan. Yogyakarta: Pustaka Pelajar.

Sugiyono. (2013). Metode Penelitian Kuantitatif, kuaitatif dan R\&D. Bandung: ALFABETA

Sumardjo, J \& Saini. (1988). Apresiasi kesusastraan. Jakarta: Gramedia 